\title{
HasanuddinLawReview
}

\section{Environmental Pollution: Assessing the Criminal Liability of Corporations}

\author{
Hariman Satria
}

Faculty of Law, Universitas Muhammadiyah Kendari, Indonesia. E-mail: hariman85antikorupsi@gmail.com

\section{ARTICLE INFO}

Keywords:

Corporation; Environmental

Crime; Environmental

Pollution; Punishment

How to cite:

Satria, H. (2018).

Environmental Pollution:

Assessing the Criminal

Liability of Corporations.

Hasanuddin Law Review,

4(2): 194-203

DOI:

10.20956/halrev.v4i2.1421

\begin{abstract}
The Supreme Court sentenced PT Dongwoo Enviromental Indonesia (PT DEI) for disposing of hazardous and toxic wastes polluting the environment. Meanwhile, PT Adei Plantation \& Industry (PT API) was charged with crime for the destruction of land damaging the environment. The research method used is normative legal research, which focuses on two approaches: case approach and conceptual approach. The results show that, first, PT DEI and PT API are charged criminally represented by the board as functioneel daderschap or directing mind and will. Second, PT DEI is charged with subsidized charges, while PT API is charged to alternative charges. Third, PT DEI and PT API are said to have committed a criminal act because management either the directors or regular employees commits a criminal offense for and on behalf of the corporation or in favor of the corporation. Fourth, to prove a corporation fault is through the aggregation of management mistakes or controlling personnel or regular employees in the corporation structure. Fifth, the principal penalty imposed on PT DEI is a fine of Rp 1.500,000,000. Similarly, PT API is fined Rp 650.000.000. Sixth; PT DEI is charged to additional crime in the form of deprivation of profits and closure of the company while PT API is an improvement due to crime. Seventh, with the closing of the company, the judges did not order the executors to liquidate the assets of PT DEI. Eighth, the imposition of the company's closing sanctions should take into account the impacts, such as the termination of employee relation and the interests of shareholders.
\end{abstract}

Copyright $\odot 2018$ HALREV. All rights reserved.

\section{Introduction}

Criminal liability of corporations has become one of the most debated topics of the 20th century. ${ }^{1}$ In Indonesia, a corporation which is suspected of committing crimes environmental pollution can be prosecuted as a criminal. It can be seen that the

1 Pop, A.I. (2006). "Criminal Liability of Corporations-Comparative Jurisprudence". Submitted in partial fulfillment of the requirements of the King Scholar Program, Michigan State University College of Law, p. 2. 
prosecution to PT DEI in Bekasi West Java (decisions of supreme of court, MA No. 862 K/pid.sus/2010) and PT API in Pekanbaru (decisions MA No. 2042 K/pid.sus/2015). Both the corporation, condemnation of the penalty for the effect of crime environmental pollution and effect of waste dangerous and toxic and may cause burning land and forest thus damage of environment. Based on this case, PT API and PT DEI are charged by a criminal in corporate responsibility.

Talking about corporate criminal liability cannot be separated from the corporation crime itself. On that basis, ideally before reviewing the corporate criminal liability then first discussed corporation crime, because corporate criminal liability is born from the womb of corporation crime itself. In short, there is a causal relationship between of corporation crime and its punishment.

John Braithwaite says corporate crime as the conduct of a corporation, or of employees acting on behalf of a corporation, which is prescribed and punishable by law. ${ }^{2}$ While Marshall B. Clinard and Peter C. Yeagar say that corporate crime is any act committed by corporation that is punished by the state, regardless of whether it is punished under administrative, civil or criminal law. ${ }^{3}$ It is including corporate crime when agent of a corporation use the corporate infrastructure or asset to commit a crime meant to boost general profits and the benefit shareholders. ${ }^{4}$

Although the doctrine of corporate crime has been acknowledged for its existence in the criminal law and criminology science, there is still debate over corporate crime. One of the impetuses is the opinion expressed by von Savigny, which states that the corporation is a fiction only, a real personality only in humans. Another challenge, Hans Kelsen says that is the preservation of principle of universitas delinquere non-potest (corporation cannot be punished) and the principle of societas delinquere non potest (corporation is not possible to commit a crime) in criminal law. ${ }^{5}$

In its development, the two reasons above gradually faded. It is recognized by Glanville Williams by saying the evolution of corporate responsibility is a striking instance of judicial change in the law. At first it was thought that a corporation was not indictable and could not commit a crime, but this rule has slowly been eroded and replaced by a wide measure of responsibility. ${ }^{6}$

Nowadays, in many countries, the corporation has been recognized as the subject of offense and may be subject to criminal liability. ${ }^{7}$ In Indonesia, the beginning of the corporation was recognized as the subject of the offense set out in the Emergency Law No. 17 of 1951 on Stockpiling of Goods. Four years later, it was re-enforced through the

2 Braithwaite, J. (1994). Corporate Crime in the Pharmaceutical Industry. London: Routledge and Kegan Paul. p. 6.

Simpson, S.S. (2005). Corporate Crime, Law and Social Control. New York: Cambridge University. p. 7.

4 Pontel, H.N., and Geis, G. (2007). International Handbook of White Collar and Corporate Crime. New York: Springer, p. 187.

Kelsen, H. (1945). General Theory of Law and State. New York: Russel \& Russel.

6 Williams, G. (1961). Criminal Law. London: Stevens \& Sons Limited. p. 853.

7 Pieth, M., and Ivory, R. (Ed). (2011). Corporate Criminal Liability: Emergence, Convergence E Risk. LondonNew York: Springer. p. 39. 
Emergency Law No. 7 of 1955 on Prosecution Investigation and Economic Crime Court. In the a quo regulation, corporation is not only defined as subjects of offense but also regulated in its criminal process. ${ }^{8}$ Especially in environmental crime, initially the provision on corporate criminal liability is regulated in Law No. 23 of 1997 on Environmental Management. Underpinned by various weaknesses, then this regulation is then replaced by Law No. 32 of 2009 on Environmental Protection and Management (PPLH law). Concerning the punishment of the corporation is stipulated in Article 116 jo Article 118 jo Article 119 of the PPLH Law. ${ }^{9}$

One of the impetuses of the amendment to the PPLH Law is to strengthen the regulation of corporate criminal liability. However, in practice there are still few corporations that are subject to criminal prosecution. The first corporation criminally charged is PT Newmont Minahasa Raya. The next charged corporations are PT Dongwoo Enviromental Indonesia (PT DEI) in Bekasi (Supreme Court Decision No. $862 \mathrm{~K} /$ Pid.Sus/2010) and PT Adei Plantation \& Industry (PT API) in Pekanbaru (Supreme Court Decision No. 2042 K/Pid.Sus/2015).

In relation to that, the authors focus on two Supreme Court decisions, namely PT DEI and PT API, which were found guilty of proven for doing environmental pollution. Practically there are two reasons that stimulate the author so interested in reviewing these two decisions. First, it has a permanent legal force (inkracht van gewijsde). Second, it is substantively related to the punishment of corporation. The question that will be answered in this research is how is the implementation of corporation punishment in the crime of environmental pollution?

\section{Method}

In accordance with the problems studied, this research is a normative legal research. To search and find answers to problems in this study, the authors use two approaches. First, the case approach (case approach), starting from the ratio decidendi that is the legal reason used by the judge to the decision. According to Goodheart, the ratio decidendi can be found by observing material facts. ${ }^{10}$ Second, the conceptual approach which is based on the views and doctrines that developed in the law science. Understanding of these views and doctrines can be a base in building and solving research problems. ${ }^{11}$

\section{Reviewing the Punishment Decision on PT DEI and PT API}

Before further reviewing the results and discussion, the author will first describe the theories of corporate criminal liability because it is related to the punishment decision on PT DEI and PT API. There are at least five theories: first, the theory of identification

8 Satria, H. (2017). “Penerapan Pidana Tambahan Dalam Pertanggungjawaban Pidana Korporasi Pada Tindak Pidana Lingkungan Hidup", Jurnal Yudisial, 10 (2) : 156.

9 Hamzah, A. (2016). Penegakan Hukum Lingkungan. Bandung: Alumni. p. 198.

10 McLeod, T.I. (1999). Legal Theory. London: Macmillan. p. 8.

11 Marzuki, P.M. (2014). Penelitian Hukum. Jakarta: Kencana Pernada Media. p. 95. 
(direct corporate criminal liability). ${ }^{12}$ According to this theory, the corporation may commit a number of offenses directly through administrator closely connected to the corporation, acting for and on behalf of the corporation so as to be seen as the corporation itself..$^{13}$

Second, strict liability. Smith and Brian Hogan, define it as crimes which do not require intention, recklessness or even negligent or more element in the actus reus. ${ }^{14} \mathrm{~A}$ similar opinion was put forward by Paul Dobson, strict liability as some crimes for which with regard to at least one element of the actus reus, no mens rea is required.15 Thus, strict liability can be interpreted as strictly liability according to the law regardless of who made mistakes. Third is vicarious liability. According to Wayne R. LaFave, vicarious liability is one wherein one person, though without personal fault, is more liable for the conduct of another. ${ }^{16}$ This teaching is closely related to doctrine of respondeat superior that is the relationship between master and servant or between principal and agent. The relationship is then reinforced by an adugium which reads qui facit per alium facit per se meaning that someone who acts through another person is considered him / her doing the deed. ${ }^{17}$

Fourth, aggregation theory. This teaching allows aggregation or a combination of errors from a number of people, to be attributed to corporations so that corporations can be held liability. ${ }^{18}$ In essence, this doctrine emphasizes that all deeds and all mental elements (mens rea) of related people relevantly in the corporation environment are considered to be done by one person only. ${ }^{19}$ Fifth, the doctrine of corporate cultural model or work culture model. The emergence of corporate cultural model theory is actually influenced by a presumption that corporate acts and policies are not simply an aggregation of individual choices but are often the acts and policies of the company itself. 20 The corporate work culture is then defined as an attitude, policy, rule, course of conduct or practice existing within the body corporate generally or within the area of the body corporate in which the relevant activities take places. ${ }^{21}$ The core of this teaching is the explicit and implicit corporate policy affecting the workings of the legal entity.

Hence, still concerning corporate criminal liability, theoretically known as three models of prosecution against corporations. First, the corporate administrator as the maker, and the administrator is charged. Second, the corporation as the maker and the

12 Pinto, A., and Evans, M. (2003). Corporate Criminal Liability. London: Sweet and Maxwell. p. 46.

13 Reid, S.T. (1995). Criminal Law. New York: Prentice Hall. p. 53.

14 Smith, J.C., and Hogan, B. (1998). Criminal Law. London: Butterworths. p. 171.

15 Dobson, P. (2008). Criminal Law. London: Thomson Sweet and Maxwell. p. 22.

16 Lafave, W.R. (2003). Principle of Criminal Law. New York: West A Thomson Reuters Bussines. p. 224.

17 Brodowski, D., and Manuel Espinoza de la Parra (Ed). (2014). Regulating Corporate Criminal Liability. New York and London: Springer. p. 11.

18 Sjahdeini, S.R. (2006). Pertanggungjawaban Pidana Korporasi. Jakarta: Grafiti Press. p. 108.

19 Clarckson and Keating (2007). Criminal Law: Text and Material. London: Thomson Sweet \& Maxwell. p. 243-244.

20 Ibid. p. 245.

21 Sutrisno, B. (2014). Strategic Step for Environmental Rescue: A Theoretical Legal Studies. Rechtsidee, 1(1), 27-58. doi: http://doi.org/10.21070/jihr.v1i1.98. 
administrator is as responsible. Third, the corporation as the maker and also as the responsible. ${ }^{22}$

Sentencing both corporation PT DEI and PT API, in fact, adopt a theory of aggregation the criminal accountability replacement. The theory of aggregation is determining what corporation is a combination of works that are done by employees. While theory criminal is accountability replacement pertains to the prosecution of corporate represented by a director. Systematically will be described as follows:

\subsection{Critical Analysis of PT DEI Decision}

Tracing the involvement of PT DEI in environmental pollution in Bekasi Regency can be seen in the legal considerations (ratio decidendi) of the judges in the a quo case. It is starting from the disposal of hazardous and toxic waste (HTW) in Sempu village, Cikarang, Bekasi Regency done recklessly by Awing, Inan, Vishnu and Dedi Permana as the administrator of PT DEI. As a result of these actions, the surrounding people have headaches, dry throat, chest tightness, stomach nausea and vomiting as contained in Visum et Repertum from Medika Hospital Cikarang. ${ }^{23}$

This disease is as a risk exposed by Ammonia gas (NH3), Hydrogen Sulphide (H2SO) and Methane contained in HTW. On this event, PT DEI is charged with PRIMAIR: violating Article 41 paragraph (1) in conjunction with Article 45 jo Article 47 of Law no. 23 of 1997 on Environmental Management jo Article 64 paragraph (1) of the Criminal Code. SUBSIDAIR: violating Article 42 Paragraph (1) in conjunction with Article 45 jo Article 47 of Law no. 23 of 1997 on Environmental Management jo Article 64 paragraph (1) of the Criminal Code. MORE SUBSIDE: violating Article 44 paragraph (1) in conjunction with Article 45 jo Article 47 of Law no. 23 of 1997 on Environmental Management jo Article 64 paragraph (1) of the Criminal Code. ${ }^{24}$

If considered then the form of indictment against PT DEI is the indictment of subsidiarity. In this Subsidair indictment, formulated or arranged several crimes in layered or stratified starting from the most serious criminal offense to the lightest. ${ }^{25}$ Simply, subsidair indictments replace the primair indictment (first indictment). And so on, the bottom order replaces the topmost. So that sometimes found the ordering of indictments of more than two or three criminal offenses. ${ }^{26}$

In its verdict of the panel of judges stated that PT DEI was legally and convincingly proven beyond the quality standards of ambient water and air then contaminate or damage the environment continuously. ${ }^{27}$ Referring to the decision of PT DEI, in order to be more constructive and the spectrum is not widespread then the author's comment

22 Muladi and Priyatno, D. (2013). Pertanggungjawaban Pidana Korporasi. Jakarta: Kencana Pernada Media. p. 86.

23 Read Supreme Court Decision No. 862 K/Pid.Sus/ 2010 on behalf of the PT DEI. p. 4.

24 Read Supreme Court Decision No. 862 K/Pid.Sus/ 2010 on behalf of the PT DEI. p. 7.

25 Harahap, M.Y. (2009), Pembahasan Permasalahan dan Penerapan KUHAP: Penyidikan dan Penuntutan. Jakarta: Sinar Grafika. p. 184.

26 Ibid, p. 212.

27 Read Supreme Court Decision No. 862 K/Pid.Sus/2010 on behalf of the PT DEI. p. 41 
will be limited to the ratio decidendi and the verdict of the panel of judges. There are four basic things that the author will describe namely: first, the determination of criminal offenses by the corporation. The judges argued that corporations had polluted the environment through the actions of some of their employees or administrators. It's just that the act was accounted for by the corporation represented by director Kim Young Woo.

Such a ratio decidendi construction implicitly embraces two theories of corporate criminal liability, namely the theory of aggregation, relating to the determination of corporation action is a combination of actions performed by employees. Another theory is the theory of vicarious liability relating to the prosecution of the corporation represented by the Director. In this case the director is accountable for the fault of the corporation. William S. Laufer states that the director is sued for being considered as a directing mind and will in the corporation. ${ }^{28}$

Second, the determination of corporation fault. In the a quo case, the judges judged the mistake of the corporation by referring to the mistakes made by its employees and directors. This can be found in the consideration of the assembly stating that the defendant of PT DEI "intentionally" releases or disposes of substances, hazardous or toxic energy. ${ }^{29}$ The point to determine the fault of PT DEI is simply to see that the actions taken by the employee, have "intentionally or knowingly or reasonably suspect" that an act can damage or pollute the environment. Thus, the employee's fault in the form of deliberate (dolus) as well as negligence (culpa) and the board of directors at the time of committing a crime are regarded as a mistake of DEI itself.

Third, the amount of fine penalty. ${ }^{30}$ If paying attention to the prosecutor's demand then compared with the decision of the panel of judges, it can be seen that the judges gave a criminal verdict of fine more severe than the prosecutor's demand. ${ }^{31}$ This is normatively not wrong, because the criminal verdict of fine is still in the corridor of Article 41 paragraph (1) and (2) of the 1997 environmental law. According to the authors, the amount of fines is very rational because almost close to the maximum penalty of fine in Article 41 paragraph (2) amounting to Rp750.000.000 (seven hundred fifty million rupiah). The maximum of fines penalty for corporate penalty will help restore the harm caused ${ }^{32}$ and as a means of prevention (general and special), the protection of society and as a retribution to give a deterrent effect to the corporation. ${ }^{33}$

28 Laufer, W.S. (2006). Corporate Bodies \& Guilty Mind: The Failure of Corporate Criminal Liability. London: The University of Chicago Press. p. 56.

29 Read Supreme Court Decision No. 862 K/Pid.Sus/2010 on behalf of the PT DEI. p. 18.

30 Read Supreme Court Decision No. 862 K/Pid.Sus/2010 on behalf of the PT DEI. p. 43. Fine penalty in case $a$ quo amount Rp650. 000.000

31 Read Supreme Court Decision No. 862 K/Pid.Sus/2010 on behalf of the PT DEI. p. 45. Fine criminal charges by JPU in case a quo amount Rp365.000.000,00.

32 Setiyono. (2003). Kejahatan Korporasi: Analisis Victimologis dan Pertanggungjawaban Pidana Korporasi Dalam Hukum Pidana Indonesia. Malang: Bayu Media. p. 130.

33 Priyatno, D. (2017). Sistem Pertanggungjawaban Pidana Korporasi Dalam Kebijakan Legislasi. Jakarta: Kencana Pernada Media. p. 114. 
Fourth, the criminal deprivation of profits earned from the crime. ${ }^{34}$ The panel of judges stated that there is a profit earned by PT DEI of US \$ 31175.2 at the time of conducting its business. ${ }^{35}$ It should be noted that in the 1997 environmental law, sanctions for the deprivation of profits from criminal offenses are part of the sanction of disciplinary action. In essence, action sanctions have a broader purpose that is as a special prevention. Through action sanctions, it is expected to improve the mental of the perpetrators of criminal offense and influence others not to take part in criminal offense as general prevention. ${ }^{36}$

In addition to profit deprivation, the other sanction of action adopted in the a quo decision is the closure of PT DEI. The imposition of such sanctions is as shut down the corporation. Suzuki, then remind that the closure of business premises not only implies on corporations but more than that, it also affects innocent people, such as employees and shareholders. ${ }^{37}$ According to the authors, which is less than the $a$ quo decision is that the judges did not specify the liquidation orders of PT DEI asset, because when the corporation is closed there must be a guarantee that the rights of others, such as creditors, will be resolved. Therefore, the verdict of the judge should ideally be accompanied by an order to the management of the corporation to liquidate the assets of the company to repay the debts of PT DEI to its creditor.

Based on the above description, it can be concluded that when one or more employees or administrator committing a crime for or on behalf of the corporation, then their deeds can be accountable to the corporation. This is as the consequence of the identification of the doctrine in corporate criminal liability. Furthermore, corporation faults are largely determined by mistake of the administrator. So, both the deliberate and negligent of administrator in committing a criminal offense, it is attributed as a corporation fault. Then with regard to criminal sanctions, corporations can only be subject to a fine. For corporations cannot be subject to crime of deprivation of liberty. Last is the model of prosecution against PT DEI. In this case follow the model, the administrators do a crime, the corporation demanded or accounted for.

\subsection{Critical Analysis of PT API Decision}

The case of PT API actually has not been too long, around 2015. This case stems from the event of burning land and forest damaging the environment of PT API in Pekanbaru area. The impact of pollution occurs in the region of Sumatra and neighboring countries such as Singapore. As a result of this incident, the police conduct investigations and investigations. In its development, investigators of Police Headquarters and Pekanbaru Police found indications of involvement of PT API as the perpetrator of burning.

\footnotetext{
34 Read Supreme Court Decision No. 862 K/Pid.Sus/ 2010 on behalf of the PT DEI. p. 43.

35 Read ratio decidendi in Supreme Court Decision No. 862 K/Pid.Sus/2010 on behalf of the PT DEI. p. 30.

36 Jan Remmelink. (2003). Hukum Pidana: Komentar atas Pasal-Pasal Terpenting dari Kitab Undang-Undang Hukum Pidana Belanda \& Padanannya Dalam Kitab Undang-Undang Hukum Pidana Indonesia. Jakarta: Gramedia Pustaka Utama. p. 458.

37 Muladi and Dwija Priyatno, Op.Cit, p. 148.
} 
PT API is then charged with an alternative indictment, namely Article 48 paragraph (1) jo Article 26 of Law no. 18 of 2004 on Plantation or Article 108 in conjunction with Article 69 paragraph (1) letter a Law no. 32 of 2009 on PPLH or Article 98 paragraph (1) in conjunction with Article 116 paragraph (1) letter a of Law no. 32 Year 2009 on PPLH. Theoretically, the indictment is an alternative form. Alternative indictment, the compilation is similar to Subsidair indictment that are accused are some criminal offenses, but in fact the indictment intended and which must be proven only one offense/indictment. Hence, it is up to the prosecutor, which indictment has been successfully proven before the court irrelevant to the sequence of charged crimes, as the case of subsidized charges. ${ }^{38}$

In conjunction with that, the authors will analyze some basic matters related to the ratio decidendi and the verdict of the panel of judges when deciding that PT API is proven in polluting the environment. First, the determination of corporation fault. In the a quo case, to determine corporation fault can be seen from a series of criminal offense committed by the administrator and corporation director Tan Kei Yong. Affirmed in the legal considerations of the assembly, that the corporation administrator and directors have not really tried to prevent and fire suppression from the beginning, so that the fire widened to an area of \pm 40 ha. ${ }^{39}$

The absence of such seriousness in the judges' consideration is then referred to as the element of "negligence (culpa)". This negligence is evidenced by the lack of a water pump machine for fire suppression owned by PT API. As a result, the fire cannot be stopped then causing a large fire. This negligence also resulted in exceeding the standard criteria of environmental damage. 40

In short, the determination of PT. API fault cannot be separated from the administrator and director's fault. The negligence (culpa) of corporation administrator and directors in preventing the occurrence of land fires is regarded as the mens rea or the negligence of the corporation itself. In short, to determine the fault of the corporation can be seen through the fault of the administrator. If the administrator is negligent, especially the director as directing mind and will, then the negligence becomes a corporation fault. Second, the penalty of fines amounting to Rp1,500,000,000 (one billion five hundred million rupiah). The amount of penalty imposed by this panel of judges is adrift with prosecution of the fine of prosecutor to the defendant amounting to Rp5,000,000,000 (five billion rupiah). This shows that the panel of judges in the a quo case tend to give a lighter penalty to the defendant PT API. Whereas, this fines penalty is a penalty type that can be used to restore the losses suffered by the state.

In addition, significant penalty of fines, at a minimum, can provide a deterrent effect to the defendant. ${ }^{41}$ Nevertheless, the fine amount of the penalty should take into account

38 H.M.A. Kuffal. (2007). Penerapan KUHAP Dalam Praktik Hukum. Malang: UMM Press. p. 213.

39 Read Supreme Court Decision No. 2042 K/Pid.Sus/2015 atas nama PT API. p. 26.

40 Read Supreme Court Decision No. 2042 K/Pid.Sus/2015 atas nama PT API. p. 27.

41 Sjahdeini, Op.Cit, p. 208. 
the financial ability of the corporation. ${ }^{42}$ Inqasu a quo, take into account the financial capability of PT API. Third, additional criminal sanction of criminal offense is Rp15. 141,826,779 (fifteen billion one hundred forty one million eight hundred twenty six thousand seven hundred seven nine rupiah). When considered additional penalty amount of criminal offense is in harmony with additional penalty prosecution by the prosecutor to the defendant. Normatively, additional penalty in the form of corrective actions due to criminal offenses are clearly stipulated in Article 119 letter c of the PPLH Law. Therefore, the additional penalty is appropriately imposed by the panel of judges whether reviewed normatively or viewed from the side of the criminal prosecutor's prosecution. Fourth, imprisonment penalty as substitute of fines. In the a quo verdict, the panels of judges handed down the imprisonment in lieu of a fine. Thus, if the corporation (PT API) cannot afford the fine then this is replaced with imprisonment for 5 (five) months. Note that the imprisonment penalty as substitute of fines is carried out by Tan Kei Yoong representing PT API in criminal justice process.

\section{Conclusion}

Based on the above review, it can be concluded that the following points are: First, PT DEI is charged with subsidized indictment, while PT API is an alternative indictment. Second, PT DEI and PT API are charged with crime represented by the administrator as functional daderschap or controlling person (directing mind and will). Third, PT DEI and PT API are said to have committed environmental pollution because the board of directors and ordinary employees commits a criminal act for and on behalf of the corporation or the action is beneficial to the corporation. Fourth, to prove a corporate fault is through error aggregation of administrator or controlling personnel in the corporation or employees in the corporate structure. Fifth, the principal criminal sanctions imposed on PT DEI and PT API is fines penalty. This is in accordance with the nature and character of corporations that are not allowed to be subject to criminal or deprivation of liberty. However, corporate administrators can still be subject to criminal deprivation of liberty as a criminal sanction. Sixth, in addition to the basic penalty in the form of fines, PT DEI and PT API are also charged to additional penalty in the form of company closure and profit deprivation obtained from a criminal offense. Seventh, in the verdict of PT DEI, additional criminal sanction in the form of company closure is imposed but the panel of judges does not include provisions on liquidation order to the administrator of PT DEI. This is important because it concerns the rights of creditors in the future when the corporation is closed. Eighth, the imposition of sanctions for the closure of the company as in the decision of PT DEI, the panels of judges should take into account the impacts, such as the termination of employee relations and the interests of shareholders.

42 Sjawie, H.F. (2013). Direksi Perseroan Terbatas serta Pertanggungjawaban Pidana Korporasi. Bandung: PT Citra Aditya Bakti. p. 92. 


\section{References}

Brodowski, D., and Manuel Espinoza de la Parra (Ed). (2014). Regulating Corporate Criminal Liability. New York and London: Springer.

Clarckson and Keating (2007). Criminal Law: Text and Material. London: Thomson Sweet \& Maxwell.

Dobson, P. (2008). Criminal Law. London: Thomson Sweet and Maxwell.

Hamzah, A. (2016). Penegakan Hukum Lingkungan. Bandung: Alumni.

Jan Remmelink. (2003). Hukum Pidana: Komentar atas Pasal-Pasal Terpenting dari Kitab Undang-Undang Hukum Pidana Belanda \& Padanannya Dalam Kitab Undang-Undang Hukum Pidana Indonesia. Jakarta: Gramedia Pustaka Utama.

Kuffal, H.M.A. (2007). Penerapan KUHAP Dalam Praktik Hukum. Malang: UMM Press.

Lafave, W.R. (2003). Principle of Criminal Law. New York: West A Thomson Reuters Bussines.

Laufer, W.S. (2006). Corporate Bodies \& Guilty Mind: The Failure of Corporate Criminal Liability. London: The University of Chicago Press.

Marzuki, P.M. (2014). Penelitian Hukum. Jakarta: Kencana Pernada Media.

McLeod, T.I. (1999). Legal Theory. London: Macmillan.

Muladi and Priyatno, D. (2013). Pertanggungjawaban Pidana Korporasi. Jakarta: Kencana Pernada Media.

Pieth, M., and Ivory, R. (Ed). (2011). Corporate Criminal Liability: Emergence, Convergence $\mathcal{E}$ Risk. London-New York: Springer.

Pinto, A., and Evans, M. (2003). Corporate Criminal Liability. London: Sweet and Maxwell.

Pontel, H.N., and Geis, G. (2007). International Handbook of White Collar and Corporate Crime. New York: Springer.

Pop, A.I. (2006). "Criminal Liability of Corporations-Comparative Jurisprudence". Submitted in partial fulfillment of the requirements of the King Scholar Program, Michigan State University College of Law.

Priyatno, D. (2017). Sistem Pertanggungjawaban Pidana Korporasi Dalam Kebijakan Legislasi. Reid, S.T. (1995). Criminal Law. New York: Prentice Hall.

Satria, H. (2017). “Penerapan Pidana Tambahan Dalam Pertanggungjawaban Pidana Korporasi Pada Tindak Pidana Lingkungan Hidup", Jurnal Yudisial, 10 (2): 156.

Setiyono. (2003). Kejahatan Korporasi: Analisis Victimologis dan Pertanggungjawaban Pidana Korporasi Dalam Hukum Pidana Indonesia. Malang: Bayu Media.

Simpson, S.S. (2005). Corporate Crime, Law and Social Control. New York: Cambridge University.

Sjahdeini, S.R. (2006). Pertanggungjawaban Pidana Korporasi. Jakarta: Grafiti Press.

Sjawie, H.F. (2013). Direksi Perseroan Terbatas serta Pertanggungjawaban Pidana Korporasi. Bandung: PT Citra Aditya Bakti.

Smith, J.C., and Hogan, B. (1998). Criminal Law. London: Butterworths.

Sutrisno, B. (2014). Strategic Step for Environmental Rescue: A Theoretical Legal Studies. Rechtsidee, 1(1), 27-58. doi: http://doi.org/10.21070/jihr.v1i1.98. 